\title{
EFFECTS OF EXTERNAL $\gamma$-RADIATION ON ADENYLATE CYCLASE ACTIVITY IN SHEEP BLOOD CELLS
}

\section{T.S. SHEVCHENKO, I.V. KONOPLEVA}

All-Russian Research Institute of Radiology and Agroecology, Federal Agency of Scientific Organizations, 109 km, Kievskoe sh., Obninsk, Kaluga Province, 239032 Russia, e-mail riar@obninsk.org, Shevchenkotatyana@yandex.ru Received March 5, 2015

\section{Abstract}

In the mechanisms of action of various adverse factors on mammals a special part is assigned to the regulatory systems. The main regulatory system of cellular metabolism is the cAMP system. Exposure of animals to external $\gamma$-radiation results in the modification of different biochemical processes in cells. In studying diversified intercellular disorders after irradiation it is, therefore, necessary to assess functioning of the cAMP system and its key enzyme, the adenylate cyclase. Note that the data published on the effect of $\gamma$-irradiation are mainly obtained with laboratory animals which are significantly different from farmed animals in the body features, whereas the effect in highly productive animals is of special interest. We studied an influence of $\gamma$-irradiation on cAMP in Tsygai sheep for the first time and showed a cAMP modification both in the lymphocytes susceptible to radiation and in the thrombocytes which are relatively resistant. In this paper the data are shown on the basal and prostaglandin $E_{1}$ stimulated activity of adenylate cyclase in radiosensitive blood cells of sheep exposed to total external $\gamma$-radiation at a dose of $4 \mathrm{~Gy}\left(\mathrm{LD}_{50 / 30}\right)$ for 15 days. In the intact sheep lymphocytes a basal and $E_{1}$ stimulated adenylate cyclase activity was $2.82 \pm 0.64 \mathrm{pmol} /\left(\mathrm{min} \times 10^{6}\right.$ cells $)$ and $2.49 \pm 0.43 \mathrm{pmol} /\left(\mathrm{min} \times 10^{6}\right.$ cells $)$, respectively, and in the thrombocytes it amounted $10.90 \pm 1.90 \mathrm{pmol} /\left(\mathrm{min} \times 10^{8}\right.$ cells $)$ and $15.70 \pm 5.70 \mathrm{pmol} /\left(\mathrm{min} \times 10^{8}\right.$ cells $)$, respectively. From the first day after exposure, changes have been revealed in all activity components of this enzyme in the lymphocytes and thrombocytes of sheep. The lymphocytes showed a 1.7-4.3-fold increase in the basal adenylate cyclase activity on days 1-15 and 1.3-3.8-fold increase in the stimulated activity on days 1-10. In thrombocytes the basal activity of adenylate cyclase increased 2.7 and 3.5 times on days 1 and 7, respectively, and the prostaglandin $E_{1}$ stimulated activity of adenylate cyclase grew 6.9 and 5.7 times on days 1 and 7 after exposure, respectively. In all other days the adenylate cyclase activity components of interest didn't practically differ from the initial level. This suggests that i) modification of adenylate cyclase activity is caused by postradiation alteration of the structural-functional condition of plasma membranes in these blood cells, and ii) in the peripheral blood there is a prevalence of more resistant to radiation damage subpopulation of lymphocytes and thrombocytes with increased adenylate cyclase activity.

Keywords: sheep, external $\gamma$-radiation, lymphocytes, thrombocytes, cyclic adenosine monophosphate system (cAMP), basal and prostaglandin $E_{1}$ stimulated activity of adenylate cyclase.

Messenger (regulatory or signal transduction) systems play a special role in mechanism of action of various adverse factors on mammalians [1-3]. The systems of cyclical adenosine and guanosine monophosphate (cAMP, cGMP), $\mathrm{Ca}^{2+}$-calmodulin and inositol phosphate are considered the most important intracellular modulators while signal molecules (hormones, mediators, transmitters) are thought as the most important extracellular ones [4-8]. The signal of many hormones, mediators and other primary messengers is transduced by socalled signaling pathways. For example, cAMP-dependent signaling is mediated by functional interaction between membrane $\beta$-adrenoreceptor, $G$-proteins and adenylate cyclase, the key enzyme of cAMP system [5, 9]. The signal from a primary messenger (signal molecule) activates the respective cytoplasmic membrane receptor, which modifies the conformation of $\mathrm{G}$-protein molecules. Depending on whether $\mathrm{G}_{\mathrm{s}^{-}}$or $\mathrm{G}_{\mathrm{i}}$-protein is activated, adenylate cyclase is either activated or inhibited, thus resulting in either stimulation or inhibition of cAMP 
(secondary messenger) synthesis [10-12]. Then, cAMP acts as a secondary intracellular messenger activating or inactivating cellular protein kinases, which phosphorylate effector proteins and modulate (increase or decrease) their activity. The resulting metabolic and functional changes specific for a particular hormonal signal modulate the respective cell functions [3, 13, 14]. The cAMP-dependent system of transmembrane signal transmission regulates cell metabolism, proliferation and differentiation. It is also important in hematopoiesis, cell immunity, apoptosis regulation, viral infections and other processes [15-23].

Intracellular messenger systems were shown to be involved in hemostasis and in platelet activation during aggregation [24]. Experiments showed that adenylate cyclase signaling participates in stimulation of biochemical processes resulting in changes of RBC pliability. Thus, the deformed RBCs are more effective in providing of oxygen to organs and tissues. The need to activate calcium signal cascade to increase the membrane and overall cellular stability was also found [25-29]. Furthermore, potential cross-interaction between cAMP and $\mathrm{Ca}^{2+}$-dependent signaling was demonstrated [30].

Experiments showed that animal exposure to $\gamma$-rays alters the organ and tissue levels of catecholamines, corticosteroids, serotonin and other biologically active substances, which serve as signal molecules activating membrane receptors of the respective signal paths [5, 31]. Laboratory [3-35] and livestock animals [36-38] showed post-radiation injury of enzymatic activity of some messenger systems in several cell populations.

External $\gamma$-radiation of mammals in the dose of 2-10 Gy first injures the hematopoietic system causing the loss of bone marrow and peripheral blood cells [31]. Thus, a question arises whether this exposure activates the cAMP-dependent signaling in radiosensitive peripheral blood cells. It should be noted that most publications on this topic are the studies in laboratory animals, which significantly differ from livestock in their physiology and resistance to radiation.

We examined basal and prostaglandin $\mathrm{E}_{1}$ stimulated activity of adenylate cyclase in sheep lymphocytes and platelets after whole-body external exposure to $\gamma$-rays.

Technique. The study was held in tsygay breed sheep $(n=16)$ of the live weight $32.35 \pm 0.08 \mathrm{~kg} / \mathrm{animal}$, kept in vivarium of All-Russian Research Institute of Radiology and Agrarian Ecology. The animal feed was balanced according to the norms set by All-Russian Research Institute of Animal Husbandry (Moscow Region). The control group comprised 8 animals kept in conditions similar to those of experimental animals. The experimental animals ( 8 sheep) were exposed to whole-body external $\gamma$-radiation in a half-lethal dose $\left(\mathrm{LD}_{50 / 30}\right)$ of $4 \mathrm{~Gy}$, dose intensity being $1 \mathrm{~Gy} / \mathrm{h}$ delivered by instrument GUZh-24 (Russia) $\left({ }^{137} \mathrm{Cs}\right.$ as radiation source; $\gamma$-quant energy of $0.67 \mathrm{meV}$ ). The radiation dose and its homogeneity were controlled by dosimeter VAJ-18 (Germany) with spherical ionization chamber VAK-253 (Germany). Homogeneity of $\gamma$-field was within $\pm 15 \%$.

Blood was taken from jugular vein before irradiation and at 1, 3, 5, 7, 10 and 15 days after it. Sodium citrate $(0.38 \%)$ was used as anticoagulant.

Sheep platelet and lymphocyte populations were isolated by a previously developed method of ours [39]. The isolated cells were twice washed in solution containing $\mathrm{NaCl}, \mathrm{KCl}, \mathrm{K}_{2} \mathrm{HPO}_{4}, \mathrm{MgCl}_{2}$, dextrose and $\mathrm{N}$-(2-hydroxyethyl)piperazine- $\mathrm{N}^{\prime}$-(2-ethane sulfonic acid) $(145,5,0.5,1,3$ and $10 \mathrm{mM}$, respectively, $\mathrm{pH}$ 7.4). Cells in these suspensions were counted in Goryaev's chamber. The platelet aliquot was frozen before the enzymatic reaction; the lymphocyte aliquot was lyzed in hypotonic medium at $4{ }^{\circ} \mathrm{C}$ for $30 \mathrm{~min}$.

Adenylate cyclase activity in cell lysates was determined according to conditions described previously [40]. $\left[{ }^{14} \mathrm{C}\right]-\mathrm{ATP}$ and $\left[{ }^{3} \mathrm{H}\right]-\mathrm{cAMP}$ (GE Health- 
care, UK) were used as labeled enzymatic reaction substrates. Enzymatic reaction products were separated by thin-layer chromatography using Silufol UV-254 plates (Chemapol, Czech Republic). The incubation medium for enzyme assay included ATP, GTP, $\mathrm{MgSO}_{4}$, ethylene-glycol-di/ $\beta$-aminoethyl ester/-N,N-acetic acid (EGTA), creatine phosphate, Tris- $\mathrm{HCl}$ at $0.5,0.1,10,2,5$ and $50 \mathrm{mM}$, respectively, as well as creatine kinase (40 units/ml) and $37 \mathrm{kBq}$ of ${ }^{14} \mathrm{C}$-ATP (pH 7.4). Reaction was carried out in cell homogenates in the presence of EGTA, phosphodiesterase inhibitor, at $30{ }^{\circ} \mathrm{C}$. Hormone-stimulated adenylate cyclase activity was assayed in the presence of prostaglandin $E_{1}\left(10^{-5} \mathrm{M}\right)$ by the difference between the results with and without the activator. Sample radioactivity was assayed by liquid scintillation counter SL-4220 (Intertechnique, France).

The statistical processing was carried out using Student's $t$-test and Microsoft Excel 2003 package. Differences between control and experimental group results were deemed significant at $\mathrm{p}<0.05$.

Results. The viability of isolated cell population was $90-95 \%$ as determined by trypan blue testing.

The basal adenylate cyclase activity is the component of the activity of cAMP-forming enzyme associated with its catalytic subunit in the absence of cell stimulation and inhibition by physiologically active compounds [41]. This activity in lymphocytes from non-irradiated sheep lymphocytes was $2.82 \pm 0.64 \mathrm{pmol} /\left(\mathrm{min} \times 10^{6}\right.$ cells $)$. These data are similar to this parameter in bovine livestock: $2.0 \pm 0.4 \mathrm{pmol} /\left(\mathrm{min} \times 10^{6}\right.$ cells $)$ [38]. Control animals showed virtually no changes in the enzyme activity throughout the study.

External $\gamma$-radiation caused an increase in basal adenylate cyclase activity in sheep lymphocytes since the day 1 after exposure (Table). At this term, it was 1.73 times higher than in intact animals. The basal activity of this enzyme in lymphocytes increased 2.15-fold and 4.32-fold on day 3 and day 5, respectively. The elevated values of this parameter were also recorded on day 7 , day 10 and day 15 when they were 2.22 times, 2.94 times, and 3.26 times higher, respectively. Thus, the basal adenylate activity in sheep lymphocytes after radiation exposure stayed 1.7-4.3 times above the baseline during the whole study.

The basal and stimulated activity of adenylate cyclase in lymphocytes and platelets of intact and irradiated tsygay breed sheep $(X \pm X$; vivarium of All-Russian Research Institute of Radiology and Agrarian Ecology, Obninsk)

\begin{tabular}{|c|c|c|c|c|}
\hline \multirow{2}{*}{$\begin{array}{l}\text { Day after } \\
\text { exposure }\end{array}$} & \multicolumn{2}{|c|}{ Lymphocytes, $\mathrm{pmol} /\left(\min \times 10^{6}\right.$ cells $)$} & \multicolumn{2}{|c|}{ Platelets, $\mathrm{pmol} /\left(\min \times 10^{8}\right.$ cells $)$} \\
\hline & basal activity & stimulated activity & basal activity & stimulated activity \\
\hline Baseline $(n=16)$ & $2.82 \pm 0.64$ & $2.49 \pm 0.43$ & $10.90 \pm 1.90$ & $15.70 \pm 5.70$ \\
\hline \multicolumn{5}{|c|}{ Control (non-irradiated $), n=8$} \\
\hline 1 & $2.66 \pm 0.64$ & $2.53 \pm 0.42$ & $10.40 \pm 1.20$ & $17.20 \pm 3.30$ \\
\hline 3 & $2.97 \pm 0.55$ & $2.34 \pm 0.36$ & $10.10 \pm 0.08$ & $16.50 \pm 2.30$ \\
\hline 5 & $2.64 \pm 0.52$ & $2.33 \pm 0.31$ & $11.20 \pm 1.30$ & $15.40 \pm 0.90$ \\
\hline 7 & $3.03 \pm 0.44$ & $2.47 \pm 0.28$ & $10.20 \pm 0.07$ & $17.20 \pm 0.80$ \\
\hline 10 & $2.92 \pm 0.36$ & $2.32 \pm 0.44$ & $9.80 \pm 1.20$ & $13.30 \pm 0.54$ \\
\hline 15 & $3.11 \pm 0.45$ & $2.45 \pm 0.33$ & $9.60 \pm 1.10$ & $13.50 \pm 0.70$ \\
\hline \multicolumn{5}{|c|}{ Test a nim a $1 \mathrm{~s}, n=8$} \\
\hline 1 & $4.88 \pm 0.56^{*}$ & $7.35 \pm 0.26^{*}$ & $26.80 \pm 7.10$ & $107.50 \pm 27.50^{*}$ \\
\hline 3 & $6.05 \pm 1.62$ & $7.33 \pm 0.11^{*}$ & $9.70 \pm 3.00$ & $16.60 \pm 6.30$ \\
\hline 5 & $12.17 \pm 1.44^{*}$ & $21.80 \pm 5.16^{*}$ & $5.10 \pm 0.60^{*}$ & $13.40 \pm 3.40^{*}$ \\
\hline 7 & $6.25 \pm 1.10^{*}$ & $5.31 \pm 1.01^{*}$ & $38.60 \pm 8.60^{*}$ & $89.50 \pm 16.50$ \\
\hline 10 & $8.30 \pm 1.90 *$ & $3.22 \pm 0.58$ & $9.50 \pm 2.10$ & $9.80 \pm 4.50$ \\
\hline 15 & $8.20 \pm 0.60^{*}$ & $6.91 \pm 0.51^{*}$ & $9.30 \pm 0.70$ & $8.30 \pm 0.30$ \\
\hline
\end{tabular}

The stimulated adenylate cyclase activity is measured in the presence of effector, prostaglandin $\mathrm{E}_{1}$ and it is related to the function of hormonal subunit of the enzyme [41]. The mean value of this parameter in lymphocytes of all 16 animals before irradiation was $2.49 \pm 0.43 \mathrm{pmol} /\left(\mathrm{min} \times 10^{6}\right.$ cells $)$. The stimulated adenylate cyclase activity was 2.95 times higher than the value in intact animals on 
day 1 after exposure. It increased 2.94 and 3.76 times on day 3 and day 5, respectively, and 1.83 and 1.29 times on day 7 and day 10, respectively. This parameter increased 2.78 times on day 15 . Thus, the adenylate cyclase activity stimulated by prostaglandin $E_{1}$ in lymphocytes after $\gamma$-radiation exposure remained elevated 1.33.8 times during the entire study.

As the basal adenylate cyclase activity is associated with catalytic subunit and the stimulated activity is associated with hormonal subunit, the progression of radiation injury in sheep resulted in increased function of both subunits in adenylate cyclase enzymatic complex of lymphocytes.

Basal activity of adenylate cyclase in platelets of all 16 intact animals was $15.70 \pm 5.70 \mathrm{pmol} /\left(\mathrm{min} \times 10^{8}\right.$ cells $)$ similar to $13.3 \pm 3.0 \mathrm{pmol} /\left(\mathrm{min} \times 10^{8}\right.$ cells $) \mathrm{re}-$ ported for bovine livestock [38]. The basal activity of the enzyme in sheep erythrocytes increased 2.73-fold on day 1 after irradiation and returned to baseline on day 3. It decreased 2.14-fold on day 5 but again elevated 3.54 times on day 7 . The further values were similar to those in control animals. Prostaglandin $\mathrm{E}_{1}$-stimulated adenylate cyclase activity in platelets increased 6.85 and 5.70 times on day 1 and day 7 after exposure, respectively. It was similar to the control values in other days.

Thus, whole-body external $\gamma$-irradiation in sheep modified adenylate cyclase activity in all examined blood cell types. Namely, radiation induces the activation of adenylate cyclase signaling both in radiosensitive lymphocytes and in platelets, which are moderately radioresistant. In lymphocytes of irradiated animals, the activity of both adenylate cyclase components increases since day 1; in platelets, the increase is observed in days 1 and 7 . The processes observed in the enzymatic complex of both cell types involve both catalytic and regulatory subunits of adenylate cyclase. The functional activity of adenylate cyclase first depends on macromolecule conformation and its interactions with cytoplasmic cell membrane component because adenylate cyclase is an integral part of this membrane [41]. Biological membranes are one of ionizing radiation cell targets [42-44]. Therefore, the altered activity of adenylate cyclase in lymphocytes and platelets is surely caused by changes in structure and function of their plasmatic membranes induced by radiation exposure.

The observed increase in adenylate cyclase activity after external $\gamma$ irradiation may be also explained by other causes. The progression of radiation injury is known to be accompanied with lymphocyte death in interphase [41]. It is manifested by changes in lymphocyte subpopulations in peripheral blood of animals: the massive loss of the most radiosensitive B-lymphocytes $\left(\mathrm{D}_{0}\right.$ is 1.2-1.8 Gy) and the increase in relative proportion of more radioresistant T-lymphocytes $\left(\mathrm{D}_{0}\right.$ is 2.0-2.5 Gy for the majority of subpopulation and it exceeds $10 \mathrm{~Gy}$ in 3-8 \% of cases) [45]. Therefore, lymphocyte population circulating in blood after radiationinduced cell death at initial and main stages of radiation injury mostly comprises the most radioresistant T-lymphocytes persisting in peripheral blood for a long time (lifespan of 200-300 days) [45, 46]. It may be reasoned that increased adenylate cyclase function in lymphocytes is related not only to the cytoplasmic membrane post-radiation modification but it is mostly is a feature of blood cells remaining in circulation after loss of the most radiosensitive lymphocyte subpopulation. It is evident that only the most radioresistant lymphocytes persist after $\gamma$-radiation in sheep peripheral blood. These cells may have different cytoplasmic membrane properties, higher content of protein [47] and intracellular calcium [48], and elevated adenylate cyclase activity.

Platelets are even more radioresistant than T-lymphocytes. The normal lifespan of platelets in circulation is 5-10 days; therefore, the peripheral blood platelet population is largely replaced within 7 days [49]. While $\gamma$-radiation effects on adenylate cyclase activity in platelets at initial period of radiation injury 
are mostly mediated by cytoplasmic membrane alterations, the enzyme activity changes on day 7 seem to be related to release of new cells with new qualitative properties from the bone marrow pool into the circulation. The new platelet population shows significantly higher adenylate cyclase activity, both basal and stimulated with prostaglandin $\mathrm{E}_{1}$.

Thus, the onset of acute radiation injury after whole-body external $\gamma$ radiation of sheep in a half-lethal dose demonstrated the modified function of adenylate cyclase both in radiosensitive lymphocytes and in relatively radioresistant platelets. Lymphocytes showed increased basal and stimulated (by prostaglandin $E_{1}$ ) activity during the entire study duration, i.e. for 15 days (the maximum was observed on day 5). In platelets, basal and stimulated adenylate cyclase activity increased 2.7- and 3.5-fold on day 1 and 6.9- and 5.7-fold on day 7 while no significant changes were observed at other time points. Therefore, adenylate cyclase signaling was activated in both cell types. The detected modification of enzyme activity seems to be caused by post-radiation alterations in structure and function of cell cytoplasmic membranes that affect enzymes of adenylate cyclase signaling cascade, and by changes in peripheral blood morphology where the cell sub-population more resistant to radiation injury and having an increased adenylate cyclase activity predominates.

\section{REFEREN CES}

1. F a lle r D.M., Shilds D. Molekulyarnaya biologiya kletki [Molecular cell biology. Guide for physicians]. Moscow, 2003.

2. Mus h k m m a rov N.N., Ku z n e t s o v L.M. Molekulyarnaya biologiya [Molecular biology]. Moscow, 2007.

3. Kulinski i V.I., Ko le s n i ch e n k o L.S. Biokhimiya, 2005, 70(5): 476-492.

4. S hirs hev S.V. Biokhimiya, 2011, 76(9): 1205-1224.

5. S mi r nov A.N. Elementy endokrinnoi regulyatsii /Pod redaktsiei V.A. Tkachuka [Factors of endocrine regulation. V.A. Tkachuk (ed.)]. Moscow, 2008.

6. Nunomura W., Takakuwa Y. Regulation of protein 4. 1R interactions with membrane proteins by $\mathrm{Ca}^{2+}$ and calmodulin. Front Biosci., 2006, 11: 1522-1539.

7. Wang N., De B ock M., D e crock E., B ol M., Gadicherla A.A., Le ybae rt L., Vinken M., Rogiers V., Bukauskas F.F., Bultynck G. Paracrine signaling through plasma membrane hemichannels. Biochimica et Biophisica Acta (BBA). Biomembranes, 2013, 1828(1): 35-50 (doi: 10.1016/j.bbamem.2012.07.002).

8. Kupchik Y.M., Barchad-Avitzur O., Ben-Chaim Y., Parnas L., Parnas H., We s s J. A novel fast mechanism for GPCR-mediated signal transduction - control of neurotransmitter release. Journal of cell biology, 2011, 192(1): 137-151 (doi: 10.1083/jcb.201007053).

9. Solomonova V.G., Avdonin P.P., Vinnichenko E.S., Sukhanova I.F., Avd o n i n P.F. Zhurnal evolyutsionnoi biokhimii i fiziologii, 2007, 43: 32-38.

10. Avd o n i n P.V. Biologicheskie membrany: zhurnal membrannoi i kletochnoi biologii, 2005, 22(1): 3-26.

11. Z a mponi G.W., C u r rie K.P.M. Regulation of $\mathrm{Ca}_{\mathrm{v}} 2$ Calcium channels by $\mathrm{G}$ protein coupled receptors. Biochimica et Biophisica Acta (BBA). Biomembranes, 2013, 1828(7): 1629-1643 (doi: 10.1016/j.bbamem.2012.10.004).

12. Sprague R., Bowles E., Stumpf M., Ricretts G., Freidman A., Hou W.H., Stephenson A., Lonigro A. Rabbit erythrocytes possess adenilate cuclase type II that is activated by the heterotrimeric $\mathrm{G}$ proteins $\mathrm{G}_{\mathrm{s}}$ and $\mathrm{G}_{\mathrm{i}}$. Pharmacol. Rep., 2005, 57: 222-228.

13. Sreighton J.R., As ada N., C o oper D.M., S teven T. Coordinate regulation of membrane cAMP by $\mathrm{Ca}^{2+}$-inhibited adenilyl cyclase and phosphodiesterase activities. Am. J. Physiol. Lung Cell Mol. Physiol., 2003, 284: 100-107.

14. Fra n c is S.H., C o r b i n J.D. Cyclic nucleotide-dependent protein kinases: intracellular receptors for cAMP and cGMP action. Crit. Rev. Clin. Lab. Sci., 1999, 36(4): 275-328 (doi: 10.1080/10408369991239213).

15. Whitefield J.F., Bounton A.L., Macmanus J.P., Korska M., Tsang B.K. The regulation of cell proliferation by calcium and cyclic AMP. Mol. Cell Biochem., 1979, 27: 155 179 (doi: 10.1007/BF00215364).

16. Avdonin P.V., Kozhevnikova L.M. Biologicheskie membrany: zhurnal membrannoi i kletochnoi biologii, 2007, 24(1): 4-31.

17. Baroja-Mazo A., B a rbera-Cremades M., Pelegrin P. The participation of plasma membrane hemichannels to purinergic signaling. Biochimica et Biophisica Acta (BBA). 
Biomembranes, 2013, 1828(1): 79-93 (doi: 10.1016/j.bbamem.2012.01.002).

18. K ha itov R.M., M a n'k o V.M., Y a rili n A.A. Uspekhi sovremennoi biologii, 2005, 125(4): 348-359.

19. K h a i t o v R.M., M a n'ko V.M., Y a rili n A.A. Uspekhi sovremennoi biologii, 2005, 125(5): 435-445.

20. Khaitov R.M., Man'ko V.M., Yarilin A.A. Uspekhi sovremennoi biologii, 2005, 125(6): 544-554.

21. K ha itov R.M., M a n'k o V.M., Y a rilin A.A. Uspekhi sovremennoi biologii, 2006, 126(1): 3-9.

22. G re e n D.R. Overview: apoptotic signaling pathways in the immune system. Immunol. Rev., 2003, 193: 5-9.

23. O rlovs k y y I.A., K o zlov V.A., T o p o r k o va L.B. Immunologiya, 2006, 27(5): 312-316.

24. Shaturnyi V.I., Shakhidzhanov S.S., Sveshnikova A.N., Pantelee v M.A. Biomeditsinskaya khimiya, 2014, 60(2): 182-200.

25. Manno S., Takakuwa Y., Mohandas N. Modulation of erythrocyte membrane mechanical function by protein 4.1 phosphorylation. J. Biol. Chem., 2005, 280: 7581-7587 (doi: 10.1074/jbc.M410650200).

26. Muravyov A.V., Che porov S.V., Kislov N.V., Volkova E.L. Macro- and microrheological changes in patients with solid tumors after treatment with recombinant erythropoetine (Epoetin-beta). Clin. Hemorheol. Microcirc., 2009, 41: 39-47.

27. Muravyov A.V., Tikhomirova I.A., Maimistova A.A., Bulaeva S.V., Zamishlay ev A.V. Crosstalk between adenylyl cyclase signaling pathway and $\mathrm{Ca}^{2+}$ regulatory mechanism under red blood cell microrheological changes. Clin. Hemorheol. Microcirc., 2010, 45: 337-345.

28. Murav'ev A.V., Koshelev V.B., Fadyukova O.E., Tikhomirova I.A., $\mathrm{M}$ a i m is t o v a A.A., B u la e v a S.V. Biologicheskie membrany: zhurnal membrannoi i kletochnoi biologii, 2011, 28(3): 174-180.

29. Murav'ev A.V., Mikhailova S.G., Tikhomirova I.A. Biologicheskie membrany: zhurnal membrannoi i kletochnoi biologii, 2014, 31(4): 270-277 (doi: 10.7868/S0233475514040069).

30. B ruce J.I., S tra u b S.V., Y u le D.I. Crosstalk between cAMP and $\mathrm{Ca}^{2+}$ signaling in nonexcitable cells. Cell Calcium, 2003, 34: 431-444.

31. Ku d ry a hov Yu.B. Radiatsionnaya biofizika (ioniziruyushchie izlucheniya) [Radiation biophysics (ionizing radiation)]. Moscow, 2004.

32. K o v a le n k o A.N., K o v a l e n k o V.V. Rol' tsiklicheskikh nukleotidov $v$ realizatsii neiroendokrinnykh sdvigov posle radiatsionnogo vozdeistviya. Sistemnye radiatsionnye sindromy [The role of cyclic nucleotides in neuroendocrine changes caused by radiation]. Nikolaev, 2008.

33. Chubanov V.S., Rogov Yu.I., Konoplya E.F., Sholukh M.V. Radiatsionnaya biologiya. Radioekologiya, 1999, 39(4): 394-398.

34. Hunt W.A., Dult o n T.K. Synthesis and degradation of cyclic nucleotides in brain after a high dose of ionizing radiation. Radiat. Res., 1981, 85(3): 604-608.

35. S o b o l e v A.S. V sbornike: Problemy prirodnoi $i$ modifitsirovannoi radiochuvstvitel'nosti [In: Natural and modified radiosensitivity]. Moscow, 1983: 205-212.

36. Sh chuki n V.M. Metabolizm tsiklicheskikh nukleotidov v limfoidnykh organakh zhvachnykh zhivotnykh pri vneshnem $i$ vnutrennem radiatsionnom vozdeistvii. Avtoreferat kandidatskoi dissertatsii [Metabolism of cyclic nucleotides in lymphoid organs of ruminants after external and internal irradiation. PhD Thesis]. Moscow, 2000.

37. Mirzoev E.B., Kobyalko V.O., Konopleva I.V., Shevchenko T.S., Gubina O.A., Ve rk h o v s k i i Yu.G. Radiatsionnaya biologiya. Radioekologiya, 2002, 42(3): 274-278.

38. S h e v c h e n k o T.S., K o n o p l e v a I.V. Sel'skokhozyaistvennaya biologiya [Agricultural Biology], 2011, 2: 63-67.

39. S h e v c h e n k o T.S. Sel'skokhozyaistvennaya biologiya [Agricultural Biology], 2007, 6: 123-126.

40. S h e v c h e n k o A.S. Sel'skokhozyaistvennaya biologiya [Agricultural Biology], 1988, 6: 124-125.

41. S o b o le v A.S. Radiatsionnaya biokhimiya tsiklicheskikh nukleotidov [Radiation biochemistry of cyclic nucleotides]. Moscow, 1987.

42. Severinovskaya E.V., Z a i chenko E.Yu. Uspekhi sovremennoi biologii, 2007, 127(3): 283-292.

43. Burlakova E.B., Atkarskaya M.V., Fatkullina L.D., Andreev S.G. Radiatsionnaya biologiya. Radioekologiya, 2014, 54(2): 162-168 (doi: 10.7868/S0869803114020040).

44. $\mathrm{M}$ a e s h i m a Y., M a k i n o H. Molecular mechanism of cell injury. Contrib. Nephrol., 2003, 139: 32-43.

45. Yarilin A.A. Deistvie ioniziruyushchei radiatsii na limfotsity (povrezhdayushchii i aktiviziruyushchii effekty). Immunologiya, 1988, 5: 5-11.

46. S e $1 \mathrm{i}$ v a $\mathrm{n}$ o v a E.I., $\mathrm{Z}$ a m u $\mathrm{l}$ a e v a I.A., $\mathrm{S}$ a e $\mathrm{n} \mathrm{k}$ o A.S. Radiatsionnaya biologiya. Radioekologiya, 2014, 54(2): 153-161 (doi: 10.7868/S0869803114020106).

47. S h e v c he n k o T.S. Sel'skokhozyaistvennaya biologiya [Agricultural Biology], 2013, 4: 115120 (doi: 10.15389/agrobiology.2013.4.115rus, 10.15389/agrobiology.2013.4.115eng).

48. S h e v c h e n k o T.S., K o n o p lev a I.V. Sel'skokhozyaistvennaya biologiya [Agricultural Biology], 2011, 2: 63-67.

49. Gresele P., Page C., Fuste r V. Platelets. Cambrige, Cambrige Academy Press, 2002. 